\title{
Miniaturized versus conventional cardiopulmonary bypass in patients undergoing coronary artery bypass surgery: impact on lymphocyte depletion and sternal wound healing
}

\author{
Fabio Capuano ${ }^{*}$, Andrea Lechiancole, Emiliano Angeloni, Massimo Goracci, Roberto Bianchini, Antonino Roscitano, \\ Cosimo Comito, Giovanni Melina, Riccardo Sinatra
}

From World Society of Cardiothoracic Surgeons 25th Anniversary Congress, Edinburgh Edinburgh, UK. 19-22 September 2015

\section{Background/Introduction}

To reduce deleterious effects of C-CPB novel concepts have been developed based on miniaturized cardiopulmonary bypass (Mini-CPB) with closed circuits, low priming volumes and optimized perfusion system. In CABG surgery, it has previously shown that the use of Mini-CPB can reduce systemic inflammation compared to $\mathrm{C}-\mathrm{CPB}$ [25] and so attenuate the pathologic effects of $\mathrm{C}-\mathrm{CPB}$.

\section{Aims/Objectives \\ The aim of this study was to compare miniaturized car- diopulmonary bypass (Mini-CPB) versus conventional cardiopulmonary bypass $(\mathrm{C}-\mathrm{CPB})$ in patients undergoing coronary artery bypass grafting (CABG) in term of ster- nal wound healing and lymphocyte depletion.}

\section{Method}

A total of 847 patients undergoing isolated coronary artery bypass grafting (CABG) surgery were studied. Exclusion criteria were: redos, emergencies, $\mathrm{CPB}$ time longer than $180 \mathrm{~min}$, antibiotic therapy within two weeks prior to surgery. Finally, 697 consecutive patients who underwent CABG, between January 2012 and September 2014, were studied prospectively. C-CPB was used in 397 (56.9\%) patients (Group A) and Mini-CPB was used in 300 (43.1\%) (Group B). Patients in the two groups were similar with respect to demographic and preoperative status. To detect lymphocyte depletion, blood was

\footnotetext{
Department of Cardiac Surgery, University of Rome "La Sapienza", Sant'
} Andrea Hospital, Rome, 00135, Italy sampled for lymphocyte measurements at three time points: preoperatively (T1), 24 (T2) and $72 \mathrm{~h}$ postoperatively (T3) The presence of infections was evaluated according to the ASEPSIS wound scoring system. Antibiotic prophylaxis with cefazolin was performed preoperatively, according to the routine of the institution.

\section{Results}

The study groups had similar EuroSCOREs. A total of 26/697 (3.7\%) patients had sternal wound infection (SWI). Patients from Group A showed a higher incidence of SWI compared to Group B $(26 / 397,56.5 \%$ vs $0 / 300,0 \%$ respectively, $p=0.002$ ). In Group A $14 / 26$ (54\%) patients developed deep SWI, and 12/26 (46\%) developed superficial SWI. The Group A but not the Group B showed significant lymphocyte depletion from preoperative during the 1st postoperative day (7.96 \pm $4,85 \%$ in Group A vs. $15.4 \pm 4.8 \%$ in Group B, p: < $0.0001)$. Also in 3rd postoperative day, lymphocyte depletion was lesser in Group B $(9.83 \pm 6.61 \%$ in Group A vs. $13.67 \pm 5.41$ in Group B, respectively, p < $0.0001)$. The most frequently cultured isolated were Staphylococcus epidermidis (37\%), Staphylococcus aureus (22.2\%). 22 (85\%) patients were treated by debridement and vacuum therapy and $4(15 \%)$ patients underwent surgical sternal reconstruction.

\section{Discussion/Conclusion}

This study shows that Mini-CPB for patients undergoing isolated CABG is associated with a reduced risk of SWI occurrence. This may be related to the lesser inflammatory response of Mini-CPB compared to $\mathrm{C}-\mathrm{CPB}$ and to 
the lesser lymphocyte depletion. Further studies are needed to confirm these findings.

Published: 16 December 2015

doi:10.1186/1749-8090-10-S1-A322

Cite this article as: Capuano et al:: Miniaturized versus conventional cardiopulmonary bypass in patients undergoing coronary artery bypass surgery: impact on lymphocyte depletion and sternal wound healing. Journal of Cardiothoracic Surgery 2015 10(Suppl 1):A322.

Submit your next manuscript to BioMed Central and take full advantage of:

- Convenient online submission

- Thorough peer review

- No space constraints or color figure charges

- Immediate publication on acceptance

- Inclusion in PubMed, CAS, Scopus and Google Scholar

- Research which is freely available for redistribution

Submit your manuscript at www.biomedcentral.com/submit
C BioMed Central 